\title{
Planning Human Resources to Achieve Organizational Effectiveness for Sports Programs in Radio \& Television Union in Arab Republic of Egypt.
}

\section{Sameh Kamal Abdel-Kader}

Lecturer, Faculty of Physical Education, Port-Said University, Egpyt.

\begin{abstract}
This study aims to know how to plan management of human resources to achieve organizational effectiveness of sports programs in Radio \& Television union in Arab Republic of Egypt through knowing the objectives of plan of human resources in sports programs in Radio \& Television union in Arab Republic of Egypt for the workers in sports programs, requirements of determining the required specialized worker, methods and models of planning human resources in media organization- steps of effective planning for human resources to achieve organizational effectiveness in sports programs, requirements of job of planner for human resources on level of sports programs, indicators of success of human resources plan in achievement of organization effectiveness in sports programs in Radio \& Television union in Arab Republic of Egypt, the researcher used the descriptive method with screening method, the sample is selected purposely from three administrative levels in management of sports programs in Radio \& Television union, number of (60) individuals, (20) individuals for pilot study, and (40) for basic study, the researcher used personal interview and questionnaire to collect data, and used suitable statistical management for nature of research, from presentation of the results and the conclusions, the study recommended application of the suggested model from results of questionnaire domains..
\end{abstract}

Key words: Planning- Human resources- organization effectiveness- sports programs - Radio \& Television union.

Introduction:

$\mathrm{T}$ he development of sports media and spread of satellite channels and sports programs is not by chance, but depends on technological element, human resource, scientific plans and informed management that is aware to importance of trained and specialized human resources, recruitment of necessary efficiencies in suitable places, the effectiveness of sports programs is linked largely to efficiency of human resources.

The management of human resources participates in achievement of organizational effectiveness through selection of workers able to innovate, update and solving work problems, development of workers abilities to perform jobs and participate directly in achievement of strategic objectives, keeping marked workers and reducing chances of their drop outside the organization through new systems for human resources. (Adel .Z: 2003)

Effective management for the organization human resources becomes a main resources for competitive advantage and may be the most important only determinant for long term performance of the organization, and its ability to attract, develop and maintain talented employees, and to help organizations in dealing with rapidly changing 
environments that could not be predicted. (Ronald J:2005), (RONALD R: 2002)

The experts of marketing and media ensured the important role of development of human resources in media, importance of availability of qualified human power that contribute to support media, it is not allowed to look for presence of good media without finding competent human power to manage it. (Faisal. S:2006)

Planning for human resources is the first process of resources management and is a strategy to get human resources for the organization, using, presenting and developing it, it is a systematic prediction for future needs to human resources quantitatively and qualitatively according to the organization strategies. (Khalid .A, 2005), (Suhaila A: 2002)

Human resources planning in media organizations helps to know the points of deficiency or excess in working power, and help in determining the fields of training activities, participate in increasing the number of competent working individuals through determining the needs quantitatively and qualitatively, and is considered basic factor in success of plans and polities of selection, recruitment, training and development. (Saleh M, 2004)

From here appears that management of human resources in sports programs is from the first important steps for success of these programs as

it deals with the most important resource in the media organization which is the human resources, the development of sports programs is not achieved only by vertical extension from increase of number of workers and the recent technologies of machines, but by integration of horizontal extension in providing human resources able to shape and train.

The scientific studies ensured the importance of human resources planning in the organization and the necessity of providing the required human resources for success and effectiveness of the organization, so this process participates in supporting different jobs of human resources management like selection, recruitment, training and development. (Ashrash .A: 2006), (Salah. H : 2009), (Fatemah. A, 2006), (Mervat .H, 2003), (Buck.M:2002)

On planning for human resources, care to some elements including nature of the planned activity, the competitive position of the organization, level of technology, the provided programs for development. (Salah Al-Deen .M : 2005)

The importance of human resources planning in sports programs in Radio \& Television union in Arab Republic of Egypt lies in that it is the governing element in success of modern media and achievement of competitive advantage and organization effectiveness for these programs, all the other resources (funding, studios, machines) makes achievement of objective possible but the qualified human resources makes these objectives real, with effectiveness that accompany the rapid progress in programs, dependence on technology in the field of sports media, increase in volume of working power and quality, achievement of organizational effectiveness of this programs.

From this point, it is evident that Egyptian media organization generally and sports programs especially live a period of change in philosophy of the country, and it will works in open competition especially with private satellite channels, this is only done through trained human element, so planning 
of human resources is related to application of the main plan or requirements of the organization form the human resources.

Judgment of the organizational effectiveness of sports programs in media organization is done through many indicators like if the organization is able to support its survival continuously in the surrounding environment, the production that satisfy the environmental needs, efficiency representing the ratio of outputs to inputs, satisfaction which is care to benefits that will return on the receiver, while in the middle term the indicators of effectiveness are represented in adaptation that the programs interact with the changes inside and outside, growth which is the ability to invest resources in training programs for workers and efforts of organizational development. (Khalil M, Khaidar K: 2000), (Al-Taher .M: 2005)

From the above, it is evident that planning of human resources in sports programs in Egyptian television faces many challenges including the great continuous development in the field of information systems and communication technologies leading to rapid exchange of information and ability to communicate with all work channels and tracking the world events accurately which leads to increase importance of achievement of competitive advantage, and finding mechanisms to achieve this administrative than other sports programs and channels which participate in review of human resources management for these sports programs to make the organizational effectiveness better to achieve the objectives and accompany the world development, also the challenges related to quality (quantitative and qualitative) the quality is basic requirement in modern time and improving performance of sports programs quantitative and qualitative related to challenge of dependence on qualified human element, its development and training as it is one of the most important criteria for quality, the challenges related to marked performance through which the sports programs search to achieve organization effectiveness, improvement of organizational performance and development of individuals performance, and new job skills, these challenges makes planning of human resources in sports programs a necessary subject so these changes face the new missions of human resources in media organizations.

The emphasize the use of information technology in planning for human resources management to develop the capacity of resources to ensure optimum employment and retention skills; carry on the activities of the Foundation to maximize the use of existing capacity, to understand the current and future requirements.( Mpolokeng, A: 2010)

The research problem lies in absence of human resources plan to estimate the needs of sports programs in Radio \& Television union from human elements with suitable skills and specialties during the current and future time period and selection of the best of these needs to achieve efficiency and organizational effectiveness of these programs and presence of special problems of excess workers in sites, and sectors with defyin other sites, dispersion between sectors of sports programs in television and sector of specialized programs (Nile Sport) and not depending on recent information systems and developed training methods to rise the level of workers which is reflected on their performance and their inability to accompany the private sports challenges and programs. 


\section{Research Objective and Questions:}

This research aims to know the steps of human resources planning to achieve the organization effectiveness in Radio \& Television union in Arab Republic of Egypt through answering the following questions :

- What are the objectives of human resources planning in sports programs in Radio \& Television union in Arab Republic of Egypt?

- What are the requirements for determination of the required specialized workers in sports programs in Radio \& Television union in Arab Republic of Egypt?

- What are the best methods and models of human resources planning in sports programs in Radio \& Television union in Arab Republic of Egypt?

- What are the steps for effective planning of human resources to achieve organizational effectiveness in sports programs in Radio \& Television union in Arab Republic of Egypt?

- What are the requirements of the job of human resources planner on the level of sports programs?

- What are the indicators of success of human resources plan in achievement of organizational effectiveness for sports programs in Radio \& Television union in Arab Republic of Egypt?

\section{Procedures:}

\section{Method:}

The researcher used the descriptive method with screening method that suite the research nature.

Research community and sample :

The research community is determined from directorates specialized in sports programs in Egyptian Radio \& Television union and workers in sports programs in general directorate of sports programs (local sports programs- world sports programs), general directorate of external recording (local sports events recording- world sports events), general directorate of preparation and execution (preparation- execution) whose number is 184 individuals from registries of general directorate of organization and method of work in Radio \& Television union.

The research sample is selected purposely from concerned directorates in sports programs (the research community) to represent the three management levels in sectors of sports programs in Egyptian television distributed as follows : 
Table (1)

Distribution of research sample on management sectors and levels of sports programs in Egyptian television.

\begin{tabular}{|c|c|c|}
\hline Sectors & Administrative level & Number \\
\hline \multirow{3}{*}{$\begin{array}{l}\text { Sports programs sector in Egyptian } \\
\text { television (first- second- satellite) }\end{array}$} & High management* & 4 \\
\hline & Intermediate management ${ }^{* *}$ & 6 \\
\hline & Executive management $* * *$ & 10 \\
\hline \multirow{3}{*}{$\begin{array}{c}\text { Sector of sports programs in } \\
\text { specialized channels (Nile Sport) }\end{array}$} & High management* & 4 \\
\hline & Intermediate management $* *$ & 6 \\
\hline & Executive management $* * *$ & 10 \\
\hline \multirow{3}{*}{$\begin{array}{c}\text { Sector of sports programs in } \\
\text { regional channels (Al-Mahrosa } \\
\text { network) }\end{array}$} & High management* & 4 \\
\hline & Intermediate management $* *$ & 6 \\
\hline & Executive management $* * *$ & 10 \\
\hline \multicolumn{2}{|c|}{ Total } & 60 \\
\hline
\end{tabular}

* Chairman and representatives of channels, general managers of directorates of preparation, execution , operation, communication, studios, general managers of sports programs) $* *$ (Editing chairman of sports programs) $* * *$ (Preparation teams, presentation, reporters, technicians, direction), the total sample is 60 individuals with exclusion of 20 individuals to make pilot study so the final main study sample is 40 individuals

\section{Data collection tools :}

The researcher used personal interview, and questionnaire as data collection tools, the questionnaire is designed through screening of literatures, researches and related references to the study subject, making personal interviews with number of sports media and sports management experts, to determine the domains of the questionnaire, determine the words and items, then present the questionnaire in its primary form on a number of experts specialized in the field of sports media and sports management, the percentage of agreement on domains and statements of the questionnaire on its final form is limited in (90-100\%).

Pilot study :

The researcher makes pilot study on a representative sample of the study community from outside the main sample, whose number are (20) individuals to estimate the scientific coefficients for data collection tools in the period from 1/12/2012 to $14 / 12 / 2012$. 


Scientific Coefficients of the
Questionnaire:

First: Validity:

1. Content validity: depend on validity of arbitration to know the suitability of statements and domains and their clarity, some statements are deleted and modify others according to experts opinions.

2. Internal consistency : the researcher used the method of internal consistency to know the internal consistency of correlation coefficients between statements and total of domains of questionnaire, the internal consistency for domain total with questionnaire as a whole, there is statistically significant correlation between statements and total of the domain with correlation coefficients ranged between (0.72 to 0.86) values higher than the table correlation 0.444 at level of significance (0.05) which indicates consistency of statements with their domains, the correlation coefficients between domains and total of questionnaire between ( 0.70 to 0.82$)$ values higher than the table correlation 0.444 at level of significance (0.05) which indicates consistency of domains with questionnaire as a whole and validity of the questionnaire.

\section{Second: Reliability:}

The researcher used the method of test re-test to get the reliability of the questionnaire, the questionnaire is presented on a sample of (20) individuals from the research community and from outside the main sample, then re-test on the same sample after estimation of correlation coefficient between the first and second applications with interval of two weeks and showed the presence of correlation between both application for domains of the questionnaire under research, the correlation coefficients ranged between (0.78- 0.80) which is higher than the table correlation 0.444 at level of significance (0.05) which indicates reliability of domains under research.

\section{Main study:}

The researcher performs the main study on the main sample which is 40 individuals in the period from $22 / 12 / 2012$ to $10 / 01 / 2013$.

The researcher used the following statistical management: Arithmetic mean- standard deviation- correlation coefficient- coefficient of internal consistency- percentage- odds weight. 
Results:

Table (2)

Odds weight, relative important for responses of the research sample on objectives of human resources planning in sports programs in Radio and television union in Arab Republic of Egypt. (n=40)

\begin{tabular}{|c|c|c|c|c|c|c|c|}
\hline \multirow{2}{*}{ No } & \multirow{2}{*}{ Statements } & \multicolumn{2}{|c|}{ Yes } & \multicolumn{2}{|c|}{ No } & \multirow{2}{*}{$\begin{array}{c}\text { Odds } \\
\text { weight }\end{array}$} & \multirow{2}{*}{$\begin{array}{c}\text { Relative } \\
\text { importance }\end{array}$} \\
\hline & & $\mathbf{N}$ & $\%$ & $\mathbf{N}$ & $\%$ & & \\
\hline & $\begin{array}{l}\text { The objectives of planning of human resources } \\
\text { in sports programs are : }\end{array}$ & & & & & & \\
\hline 1 & $\begin{array}{l}\text { Determining needs of sports programs in } \\
\text { workers quantitative and qualitative }\end{array}$ & 35 & 87.5 & 5 & 12.5 & 110 & $91.6 \%$ \\
\hline 2 & $\begin{array}{l}\text { Achieving stability for workers in sports } \\
\text { programs }\end{array}$ & 30 & 75 & 10 & 25 & 100 & $83.3 \%$ \\
\hline 3 & $\begin{array}{l}\text { Attracting and selecting human resources able } \\
\text { to achieve objectives of sports programs }\end{array}$ & 32 & 80 & 8 & 20 & 104 & $86.7 \%$ \\
\hline 4 & Promotion of workers in sports programs & 33 & 82.5 & 7 & $\mathbf{1 7 . 5}$ & 106 & $88.3 \%$ \\
\hline 5 & $\begin{array}{c}\text { Development of abilities and skills of workers in } \\
\text { sports programs }\end{array}$ & 32 & 80 & 8 & 20 & 104 & $86.7 \%$ \\
\hline 6 & $\begin{array}{l}\text { Planning help for good distribution of human } \\
\text { resources according to specialties and skills }\end{array}$ & 38 & 95 & 2 & 5 & 116 & $96.7 \%$ \\
\hline 7 & $\begin{array}{l}\text { Preparing for dealing with changing work } \\
\text { environment from size, growth, and } \\
\text { development in sports programs }\end{array}$ & 31 & 77.5 & 9 & 22.5 & 102 & $85 \%$ \\
\hline 8 & $\begin{array}{l}\text { Providing required information of activities of } \\
\text { human resources in sports programs }\end{array}$ & 33 & 82.5 & 7 & 17.5 & 106 & $88.3 \%$ \\
\hline 9 & $\begin{array}{l}\text { Achieving the individual objectives by putting } \\
\text { individuals in suitable works to satisfy their } \\
\text { motives and use their abilities }\end{array}$ & 38 & 95 & 2 & 5 & 116 & $96.7 \%$ \\
\hline 10 & $\begin{array}{l}\text { Reduction of hidden unemployment by getting } \\
\text { rid of excess and gapping the deficiency }\end{array}$ & 26 & 65 & 14 & 35 & 92 & $76.7 \%$ \\
\hline 11 & $\begin{array}{c}\text { Providing the sports programs with fair system } \\
\text { for selection ad recruitment }\end{array}$ & 29 & 72.5 & 11 & 27.5 & 98 & $81.7 \%$ \\
\hline
\end{tabular}


Table (3)

Odds weight, relative important for responses of the research sample on requirements of determining the required specialized workers in sports programs in Radio and television union in Arab Republic of Egypt. $\quad(n=40)$

\begin{tabular}{|c|c|c|c|c|c|c|c|}
\hline \multirow{2}{*}{ No } & \multirow{2}{*}{ Statements } & \multicolumn{2}{|c|}{ Yes } & \multicolumn{2}{|c|}{ No } & \multirow{2}{*}{$\begin{array}{c}\text { Odds } \\
\text { weight }\end{array}$} & \multirow{2}{*}{$\begin{array}{c}\text { Relative } \\
\text { importance }\end{array}$} \\
\hline & & $\mathbf{N}$ & $\%$ & $\mathbf{N}$ & $\%$ & & \\
\hline & $\begin{array}{l}\text { Determining the size of workers in sports } \\
\text { programs required the following : }\end{array}$ & & & & & & \\
\hline 12 & $\begin{array}{c}\text { Determining requirements of workers needs } \\
\text { according to the future plan of media } \\
\text { organization }\end{array}$ & 33 & 82.5 & 7 & 17.5 & 106 & $\mathbf{8 8 . 3 \%}$ \\
\hline 13 & $\begin{array}{c}\text { The managers requests of workers quantitative } \\
\text { and qualitative regarding numbers, skills and } \\
\text { specialties }\end{array}$ & 29 & 72.5 & 121 & 27.5 & 98 & $81 . \%$ \\
\hline 14 & $\begin{array}{c}\text { Analysis of jobs and characteristics of job } \\
\text { occupiers. }\end{array}$ & 38 & 95 & 2 & 5 & 116 & $96.7 \%$ \\
\hline 15 & $\begin{array}{c}\text { Study of work places regarding : division of } \\
\text { work places to groups and determining work to } \\
\text { be achieved }\end{array}$ & 37 & 92.5 & 3 & 7.5 & 114 & $95 \% \%$ \\
\hline 16 & $\begin{array}{c}\text { Number of days of work in main and } \\
\text { additional programs }\end{array}$ & 35 & 87.5 & 5 & 12.5 & 110 & $91.6 \%$ \\
\hline & $\begin{array}{l}\text { Determining required numbers of workers in } \\
\text { work places through }\end{array}$ & & & & & & \\
\hline 17 & $\begin{array}{c}\text { Volume of programs multiplied in number of } \\
\text { ours to which added number of similar work } \\
\text { places multiplied in number of works per year } \\
\text { on average number of years for each type of } \\
\text { workers }\end{array}$ & 30 & 75 & 10 & 25 & 100 & $83.3 \%$ \\
\hline 18 & $\begin{array}{l}\text { Studying the fixed percentage through analysis } \\
\text { of comparisons between many media } \\
\text { organization on level of each activity }\end{array}$ & 25 & 62.5 & 15 & 37.5 & 90 & $75 \%$ \\
\hline 19 & $\begin{array}{l}\text { Determining the job requirements from duties } \\
\text { and responsibilities, also characteristics of job } \\
\text { occupiers regarding experience, qualification } \\
\text { and type }\end{array}$ & 40 & 100 & $\mathbf{0}$ & $\mathbf{0}$ & 120 & $100 \%$ \\
\hline 20 & $\begin{array}{l}\text { Promotion and transfer to vary in workers } \\
\text { experiences in case of absence of these } \\
\text { experiences outside the media organizations }\end{array}$ & 15 & 37.5 & 25 & 62.5 & 70 & $58.3 \%$ \\
\hline 21 & Attraction of the required workers & 24 & 60 & 16 & 40 & 88 & $73.3 \%$ \\
\hline
\end{tabular}


Table (4)

Odds weight, relative important for responses of the research sample on the best methods and models for human resources planning in sports programs in Radio and television union in Arab Republic of Egypt. $(n=40)$

\begin{tabular}{|c|c|c|c|c|c|c|c|}
\hline \multirow{2}{*}{ No } & \multirow{2}{*}{ Statements } & \multicolumn{2}{|c|}{ Yes } & \multicolumn{2}{|c|}{ No } & \multirow{2}{*}{$\begin{array}{c}\text { Odds } \\
\text { weight }\end{array}$} & \multirow{2}{*}{$\begin{array}{l}\text { Relative } \\
\text { importance }\end{array}$} \\
\hline & & $\mathbf{N}$ & $\%$ & $\mathbf{N}$ & $\%$ & & \\
\hline & $\begin{array}{l}\text { The best methods of human resources } \\
\text { planning : }\end{array}$ & & & & & & \\
\hline 22 & $\begin{array}{l}\text { Model of statistical information and } \\
\text { information systems that depends on } \\
\text { (skeletal analysis of workers, rates of } \\
\text { performance, statistics of real } \\
\text { performance, using human resources and } \\
\text { its cost, salaries, awards, incentives, } \\
\text { transports, promotions, growth, ratio of } \\
\text { workers to programs volume, } \\
\text { establishment of data bases, dependence } \\
\text { on technology and computer, statistical } \\
\text { relationships). }\end{array}$ & 34 & 85 & 6 & 15 & 108 & $90 \%$ \\
\hline 23 & $\begin{array}{l}\text { Models of work centers that depends on } \\
\text { (determining characteristics of persons, } \\
\text { determining the gap, quantity and quality } \\
\text { of work centers, quantity and quality of } \\
\text { human resources, evaluation of position } \\
\text { of human organization, selection, } \\
\text { recruitment, promotion, training, } \\
\text { description of activities, improvement } \\
\text { and development of planning process } \\
\text { continuously. }\end{array}$ & 36 & 90 & 4 & 10 & 112 & $93.3 \%$ \\
\hline 24 & $\begin{array}{l}\text { Model of internal and external } \\
\text { environment analysis through (internal } \\
\text { environment represented in objectives } \\
\text { and policies of media organization, } \\
\text { volume of establishment, sports } \\
\text { programs, degree of stability, funding, } \\
\text { needs from external workers, needs from } \\
\text { external organizations, needs from other } \\
\text { organizations, external environment } \\
\text { represented in volume and description of } \\
\text { people, economical development, } \\
\text { competitive position). }\end{array}$ & 31 & 77.5 & 9 & 22.5 & 102 & $85 \%$ \\
\hline 25 & $\begin{array}{c}\text { The sports programs put special models } \\
\text { based on work circumstances and nature, } \\
\text { level of workers skeleton, level of } \\
\text { productivity, rates of performance }\end{array}$ & 39 & 97.5 & 1 & 2.5 & 118 & $98.3 \%$ \\
\hline 26 & $\begin{array}{l}\text { Integration of more than one model } \\
\text { according to abilities of the sports } \\
\text { programs and their media organization }\end{array}$ & 39 & 97.5 & 1 & 2.5 & 118 & $98.3 \%$ \\
\hline
\end{tabular}


Table (5)

Odds weight, relative important for responses of the research sample on steps of effective planning for human resources to achieve organizational effectiveness in sports programs

\begin{tabular}{|c|c|c|c|c|c|c|c|}
\hline \multirow{2}{*}{ No } & \multirow{2}{*}{ Statements } & \multicolumn{2}{|c|}{ Yes } & \multicolumn{2}{|c|}{ No } & \multirow{2}{*}{$\begin{array}{c}\text { Odds } \\
\text { weight }\end{array}$} & \multirow{2}{*}{$\begin{array}{c}\text { Relative } \\
\text { importance }\end{array}$} \\
\hline & & $\mathbf{N}$ & $\%$ & $\mathbf{N}$ & $\%$ & & \\
\hline & $\begin{array}{c}\text { Steps of effective planning to achieve } \\
\text { organizational effectiveness n sports programs } \\
\text { as follows : }\end{array}$ & & & & & & \\
\hline 27 & $\begin{array}{c}\text { Presence of separate directorate for human } \\
\text { resources in sports programs }\end{array}$ & 38 & 95 & 2 & 5 & 116 & $96.7 \%$ \\
\hline 28 & $\begin{array}{c}\text { Analysis of work environment (internal and } \\
\text { external) }\end{array}$ & 36 & 90 & 4 & 10 & 112 & $93.3 \%$ \\
\hline 29 & $\begin{array}{l}\text { Determining basic strategies for human } \\
\text { resources in sports programs }\end{array}$ & 37 & 92.5 & 3 & 7.5 & 114 & $95 \%$ \\
\hline 30 & $\begin{array}{c}\text { Growth strategies : using available chances, } \\
\text { providing new sports programs and } \\
\text { development of current sports programs and } \\
\text { recruiting new workers }\end{array}$ & 34 & 85 & 6 & 15 & 108 & $90 \%$ \\
\hline 31 & $\begin{array}{c}\text { Shrinkage strategy: get rid of some programs } \\
\text { and workers that do not achieve objectives } \\
\text { and enough to use some workers with } \\
\text { experience and skills }\end{array}$ & 28 & $\mathbf{7 0}$ & 12 & 30 & 96 & $80 \%$ \\
\hline 32 & $\begin{array}{c}\text { Stability strategy : maintaining the current } \\
\text { situation and development without adding } \\
\text { new workers through training and } \\
\text { development of current workers }\end{array}$ & 33 & 82.5 & 7 & 17.5 & 106 & $88.3 \%$ \\
\hline 33 & $\begin{array}{l}\text { Prediction of request on human resources by } \\
\text { estimation of quantity and quality of workers } \\
\text { according to the environmental changes }\end{array}$ & 27 & 67.5 & 13 & 32.5 & 94 & $78.3 \%$ \\
\hline 34 & Prediction of method of experts estimation & 10 & 25 & 30 & 75 & 60 & $50 \%$ \\
\hline 35 & $\begin{array}{c}\text { Prediction of method of management } \\
\text { requirements }\end{array}$ & 20 & 50 & 20 & 50 & 80 & $66.7 \%$ \\
\hline 36 & $\begin{array}{c}\text { Prediction of general attitude toward workers } \\
\text { data in previous years from increase or } \\
\text { decrease }\end{array}$ & 22 & 55 & 18 & 45 & 84 & $70 \%$ \\
\hline 37 & Prediction of methods advanced sports models & 30 & 75 & 10 & 25 & 100 & $83.3 \%$ \\
\hline 38 & $\begin{array}{c}\text { Analysis of the available workers from volume } \\
\text { and type of current workers, determining } \\
\text { available humans skills and experiences }\end{array}$ & 38 & 95 & 2 & 5 & 116 & $96.7 \%$ \\
\hline 39 & $\begin{array}{l}\text { Forming information system about human } \\
\text { resources (date of the employee in the } \\
\text { occupied jobs, current skills, training). }\end{array}$ & 40 & 100 & $\mathbf{0}$ & 0 & 120 & $100 \%$ \\
\hline
\end{tabular}


Table (6)

Odds weight, relative important for responses of the research sample on requirements of human resources planner job on the level of sports programs.

\begin{tabular}{|c|c|c|c|c|c|c|c|}
\hline \multirow{2}{*}{ No } & \multirow{2}{*}{ Statements } & \multicolumn{2}{|c|}{ Yes } & \multicolumn{2}{|c|}{ No } & \multirow{2}{*}{$\begin{array}{c}\text { Odds } \\
\text { weight }\end{array}$} & \multirow{2}{*}{$\begin{array}{c}\text { Relative } \\
\text { importance }\end{array}$} \\
\hline & & $\mathbf{N}$ & $\%$ & $\mathbf{N}$ & $\%$ & & \\
\hline 40 & $\begin{array}{l}\text { Knowledge of external environment: from } \\
\text { economical aspects, work laws, technological } \\
\text { development, similar organizations }\end{array}$ & 28 & 70 & 12 & 30 & 96 & $80 \%$ \\
\hline 41 & $\begin{array}{l}\text { Knowledge of internal environment from } \\
\text { strategies, objectives of the organization, } \\
\text { administrative and technical systems, in } \\
\text { sports programs }\end{array}$ & 38 & 95 & 2 & 5 & 116 & $96.7 \%$ \\
\hline 42 & $\begin{array}{l}\text { Assistant knowledge: from statistics, } \\
\text { analysis of work, job psychology, } \\
\text { organization economy, methods of interview } \\
\text { and selection }\end{array}$ & 27 & 67.5 & 13 & 32.5 & 94 & $\mathbf{7 8 . 3 \%}$ \\
\hline 43 & $\begin{array}{c}\text { Effective knowledge: from basic concepts in } \\
\text { planning of human resources . }\end{array}$ & 40 & 100 & $\mathbf{0}$ & $\mathbf{0}$ & 120 & $100 \%$ \\
\hline 44 & Analysis of organizational skeleton & 37 & 92.5 & 3 & 7.5 & 114 & $95 \%$ \\
\hline 45 & Methods of human resources planning & 40 & 100 & $\mathbf{0}$ & 0 & 120 & $100 \%$ \\
\hline 46 & $\begin{array}{c}\text { Basic skills : represented in preparing data } \\
\text { collection models for processes of human } \\
\text { resources planning }\end{array}$ & 40 & 100 & 0 & 0 & 120 & $100 \%$ \\
\hline 47 & $\begin{array}{c}\text { Effective communication in media } \\
\text { organization }\end{array}$ & 40 & 100 & 0 & 0 & 120 & $100 \%$ \\
\hline
\end{tabular}


Table (7)

Odds weight, relative important for responses of the research sample on indicators of success of human resources plan in achieving organizational effectiveness of sports programs. $(n=40)$

\begin{tabular}{|c|c|c|c|c|c|c|c|}
\hline \multirow{2}{*}{ No } & \multirow{2}{*}{ Statements } & \multicolumn{2}{|c|}{ Yes } & \multicolumn{2}{|c|}{ No } & \multirow{2}{*}{$\begin{array}{c}\text { Odds } \\
\text { weight }\end{array}$} & \multirow{2}{*}{$\begin{array}{c}\text { Relative } \\
\text { importance }\end{array}$} \\
\hline & & $\mathbf{N}$ & $\%$ & $\mathbf{N}$ & $\%$ & & \\
\hline & Internal indicators & & & & & & \\
\hline 48 & $\begin{array}{c}\text { Ability of sports programs to determine } \\
\text { objectives and plan the flow of achievement of } \\
\text { these objectives }\end{array}$ & 36 & 90 & 4 & 10 & 112 & $93.3 \%$ \\
\hline 49 & $\begin{array}{l}\text { To achieve organization effectiveness the } \\
\text { workers in sports programs must have skills and } \\
\text { technical experiences related to achieve works }\end{array}$ & 40 & 100 & $\mathbf{0}$ & $\mathbf{0}$ & 120 & $100 \%$ \\
\hline 50 & $\begin{array}{c}\text { Participation of workers in sports programs in } \\
\text { planning leads to support of organizational } \\
\text { effectiveness }\end{array}$ & 38 & 95 & 2 & 5 & 116 & $96.7 \%$ \\
\hline 51 & $\begin{array}{l}\text { Care to programs of sports programs workers } \\
\text { training and so rise of level of their performance } \\
\text { in the work }\end{array}$ & 38 & 95 & 2 & 5 & 116 & $96.7 \%$ \\
\hline 52 & $\begin{array}{c}\text { Efficiency of use of available human resources to } \\
\text { be low cost compared to returns and outputs }\end{array}$ & 33 & 82.5 & 7 & $\mathbf{1 7 . 5}$ & 106 & $88.3 \%$ \\
\hline 53 & $\begin{array}{l}\text { Job satisfaction of workers is an important } \\
\text { indicator in determining level of effectiveness of } \\
\text { human resources plan and performance of } \\
\text { individuals in sports programs }\end{array}$ & 40 & 100 & $\mathbf{0}$ & $\mathbf{0}$ & 120 & $100 \%$ \\
\hline & External indicators & & & & & & \\
\hline 54 & $\begin{array}{c}\text { Achievement of competitive advantage with } \\
\text { other sports programs }\end{array}$ & 32 & 80 & 8 & 20 & 104 & $86.7 \%$ \\
\hline 55 & $\begin{array}{c}\text { Increase request on workers from external } \\
\text { establishments }\end{array}$ & 22 & 55 & 18 & 45 & 84 & $70 \%$ \\
\hline 56 & $\begin{array}{l}\text { Rise of level of quality to sports programs } \\
\text { outputs considered necessary indicator for its } \\
\text { effectiveness }\end{array}$ & 36 & 90 & 4 & 10 & 112 & $93.3 \%$ \\
\hline 57 & $\begin{array}{c}\text { Ability to grow and develop in quantity and } \\
\text { quality of sports programs }\end{array}$ & 40 & 100 & $\mathbf{0}$ & 0 & 120 & $100 \%$ \\
\hline 58 & $\begin{array}{l}\text { Success of sports programs in survival for long } \\
\text { period means that what is presented suit the } \\
\text { environment in which we live }\end{array}$ & 30 & 75 & 10 & 25 & 100 & $83.3 \%$ \\
\hline 59 & $\begin{array}{l}\text { Introducing elements of technology and } \\
\text { introducing training programs for individuals } \\
\text { suiting the scientific development }\end{array}$ & 40 & 100 & $\mathbf{0}$ & 0 & 120 & $100 \%$ \\
\hline
\end{tabular}




\section{Discussions:}

Discussion of results of first question :

What are the objectives of human resources planning in sports programs in Radio \& Television union in Arab Republic of Egypt?

It is shown from table (2) that responses of the research sample ranged between (6595\%) for response with Yes and between (5$35 \%$ ) for response with No, odds weight of statements ranged between (96.7- 76.7\%) which indicates agreement on opinion of research sample on objectives of human resources planning in sports programs represented according to their relative important in good distribution of human resources according to specialties and skills, achieving the individual objective through putting individuals in works suitable to satisfy their motives and use their abilities, determine needs of sports programs from workers in quantity and quality, providing necessary information for activity of human resources management in sports programs, promotion of workers in sports programs, attraction and selection of human resources able to achieve the objectives of sports programs, development of abilities and skills of workers in sports programs, preparing to deal with changing work environment from volume, growth and development in sports programs, achievement of stability for workers in sports programs, providing sports programs with fair system of selection and recruitment, reducing the volume of hidden unemployment by getting rise of excess and providing deficiency with relative importance ranged from (76.7-96.7\%).

The researcher sees that these results ensured on care of workers in sports programs for priorities of distribution of human resources in sports programs according to specialties and skills and not only experiences or compliments which works to satisfy the motives, using abilities and promoting workers to perform while reducing volume of hidden unemployment and get rid of excess in the last priorities for the nature of economical position and difficulty of overcoming the problem of unemployment in Egypt but is an important and necessary request, this is in agreement with results that referred to effect of policies of directorate of human resources on development of innovative abilities of workers and promoting them for effective performance. (Fatemah. A, 2006), (Buck.M:2002)

Discussion of results of second question : What are the requirements for determination of the required specialized workers in sports programs in Radio \& Television union in Arab Republic of Egypt?

It is shown from table (3) that responses of research sample ranged between (60-100\%) for response with Yes and between (0$62.5 \%$ ) for response with No, odds weight for statements ranged between (70-120\%) which showed agreements of research sample opinion for determination of volume of workers in sports programs and according to relative importance to determine workers required in places of work through determination of requirements of jobs including duties and responsibilities and also description of job occupiers including the qualification, experience and type, analysis of jobs, review of characteristics of job occupiers, study of work placed regarding division of work places to groups, determination of work required to achieve, number of work days in basic and additional programs, determination of needs of sports programs from workers in the light of future media establishments plans, volume of programs multiplied in number of hours added to them number of similar work places multiplied in number of work days in the 
year on average number of days on quality from workers, requests of managers from workers in quantity and quality regarding numbers, skills and specialties, studying the fixed percentages from analysis of comparisons between many media organizations on the level of one activity, attraction of the required workers with relative important ranged between (58.3$100 \%)$.

The researcher attributed these results to that determination of workers volume in sports programs is related basically with accurate determination of requirements of jobs, studying the work places, their classification and determination of required workers in work places through use of some statistical methods suitable for this purpose, this is in agreement with what is mentioned in references and studies that efficiency of management of human resources is represented in determining the qualified resources to recruit the required competencies in suitable places in the organization according to scientific criteria (1), (10), while transfer and promotion as some jobs are occupied to vary the workers experiences in case of absence of these experiences outside the media organization the highest response (No) reach $62.5 \%$ and the researcher attributed this to objection that the objective is only filling the deficiency by any method by transferring non specialized individuals to occupy some places which allows chances for personal intervention and compliments.

Discussion of results of third question : What are the best methods and models of human resources planning in sports programs in Radio \& Television union in Arab Republic of Egypt?

It is shown from table (4) that responses of research sample ranged from (77.5-97.5\%) for response with Yes and between (2.5$22.5 \%$ ) for response No with odds weight of statements ranged between (102-118\%) which shows agreement of research sample opinions that the best method for planning of human resources for sports programs according to the relative importance is represented in that sports programs put special models based on work circumstances and nature and level of workers skeleton and level of productivity, rates of performance and integration between more than one model according to facilities of sports programs and media organization belonging to it, model of work centers that depends on determination of personal characteristics, determining the gap, quantity and quality of work center, quantity and quality of human resources, evaluation of human organizational position, selection, recruitment, promotion, training, description of activities, improvement and development of planning continuously, models of statistical information, information systems that depends on skeletal analysis for workers, rates of performance, real performance statistics, using human resources and their cost, salaries, awards, incentives, transfer, promotions, growth, ratio of workers to volume of programs, establishment of data bases, dependence on technology and computer, statistical relationships, model of analysis of internal and external analysis than through internal environment represented in objectives and policies of media organization, volume of organization and sports programs, degree of stability, funding, needs from external workers, needs from other organization, external environment represented in volume and characteristics of people, economical situation, technological development, competitive situation, with relative importance ranged between (85$98.3 \%$ ). 
The researcher sees that these results ensured the preference of integration of more than one model and method of human resources planning according to nature and volume of sports programs, policy of the channel, internal and external elements based on using statistical information and recent information systems.

This is what ensured from references and studies about necessity of presence of systematic predictions about future needs to human resources in quantity and quality according to organization strategies and accordingv to internal and external environmental analysis. (Khalil M, Khaidar K: 2000), (Saleh M, 2004)

Discussion of results of fourth question : What are the steps for effective planning of human resources to achieve organizational effectiveness in sports programs in Radio \& Television union in Arab Republic of Egypt?

It is shown from table (5) that responses of research sample ranged between (50-100\%) for response Yes and between (0-30\%) for response No with odds weight for statements ranged between (60-120\%) which indicates agreement of research sample opinion that the most important steps for effective planning of human resources according to relative importance is represented in formation of information systems for human resources with brief of the employee in jobs he occupied current skills, training, presence of independence management of human resources for sports programs, analysis of available workers from volume and type of current workers, determining available human skills and experiences, determining basic strategies for human resources in sports programs. Analysis of work environment (internal and external), growth strategy: using available chances, providing new sports programs, development of current sports programs, recruitment of new workers, strategy of stability: maintaining the current situation, development without adding new workers through training and development, of current workers, prediction of method of advanced sports models, strategy of shrinkage : get rid of some workers and programs that do not achieve the objectives and enough for some workers those having experience and skills, prediction of request on human resources by estimation of quantity and quality of workers according to environmental variables, prediction of general attitude through data of workers in the previous years from increase or decrease, prediction of management needs, with relative importance ranged between (50$100 \%$ )

The researcher returned these results to preferences of workers in sports programs in use of recent technology, information systems, desire in development that become a feature of the recent sports media, to facilitate access to information when needed, and necessity for presence of independent management for human resources in organization skeleton of the channel and preference of strategies of growth and development to achieve organizational effectiveness and to compete with private channels and programs.

These results are in agreement with what is mentioned in references and studied that on planning care for level of the used technology, the presented programs for development to achieve organizational effectiveness and competitive advantage. (Salah. H : 2009), (Fatemah. A, 2006), (Ashrash .A: 2006).

While prediction with method of experts estimation (personal estimation) with the highest response (No) reach $75 \%$ and the researcher found that not preferring the 
personal estimation and its entrance in prediction of request on human resources with estimation of quantity and quality of workers to achieve objectivity.

Discussion of results of fifth question : What are the requirements of the job of human resources planner on the level of sports programs?

It is shown from table (6) that response of research sample ranged between (70-100\%) for response Yes, and between (0-13\%) for response No, with odds weight for statements ranged between (94-120\%). Which indicates agreement of research sample opinions on the most important functions of human resources planners on the level of sports programs according to their relative importance represented in the effective knowledge: from the basic concepts in human resources planning for media organization, methods of human resources planning, effective communication in media organization, basic skills: represented in preparing models of information collection for processes of human resources planning, analysis of organizational skeleton, knowledge of internal environment: from organization strategy and objectives, administrative and technical systems for sports programs, external environmental knowledge: from economical aspect, labor laws, technological development, similar establishments, assistant knowledge: from statistics, analysis of work, psychology of professions, economies of establishment, method of interview and selection, with relative importance ranged between (78.3$100 \%$ ).

The researcher attributed these results to importance of integration between basic knowledge for planning methods and basic skills for planning processes and effective communication, internal and external environmental knowledge for human resources planner to be able to achieve requirements for effective sports program.

Discussion of results of sixth question : What are the indicators of success of human resources plan in achievement of organizational effectiveness for sports programs in Radio \& Television union in Arab Republic of Egypt?

It is shown from table (7) that responses of research sample ranged between (55-100\%) for response Yes and between (0-18\%) for response No with odds ratio of statements ranged between (84-120\%).

Which indicates agreement of research sample opinion on the success indicators of human resources plan in achievement of organizational effectiveness of sports programs according to relative importance lying in internal indicators as the workers in sports programs are characterized by skills and technical experiences related to achievement of works, job satisfaction of workers is an important indicators in determining level of effectiveness of human resources plan and performance of individuals in sports programs, participation of workers in sports programs in planning leads to support of organizational effectiveness, care for training programs in sports programs and so rise their levels of performance in work, ability of sports programs on determining objectives and planning the way to achieve these objectives, efficiency of using available human resources so the low cost compared with returns and outputs, external indicators like ability to grow and develop in quantity and quality of sports programs, entering elements of technology and entering training programs for individuals in a shape suiting the scientific development, ability to grow and develop in quantity and quality of sports 
programs, entering elements of technology and training programs of individuals that suit the scientific development, achievement of competitive advantage with other sports programs, success of sports programs in survival for long periods means that what is provided suit the environment in which we lives, increase of demand on workers from external organization with relative importance ranged between (70-100\%).

The researcher returned the previous results to the organizational effectiveness of sports program required achievement of group of indicators on the level of media organization and on the level of surrounding environment and participates in achievement of good planning of human resources that without trained qualified human resources do not achieve any effectives whatever the used technologies and machines.

This is in agreement with the results that judgment on effectiveness is through many indicators like ability of organization to support its survival in the surrounding environment, Market position of the media depends on the way in which these institutions are managed and the radical changes in the operating environment on which they depend management of media organizations satisfaction which care to benefits as social system, growth and ability to invest resources in training programs for workers. (Suhaila A: 2002), (Khalid .A, 2005),( Christian S. Nissen: 2013)

From the above results and discussion, appeared the answers on research questions.

\section{Conclusions:}

From presenting and discussing the results appeared that to plan the human resources to achieve organizational effectiveness for sports programs in Radio and Television
Union in Arab Republic of Egypt must include the following :

- Objectives of planning and putting in priorities distribution of human resources in sports program according to specialties and skills and attraction of individuals able to achieve objectives working to satisfy motives and using abilities and promotion of workers on performance and develop abilities and skills, with provision of data required to manage human resources in sports programs, providing sports programs with fair system for selection and recruitment to reduce the size of hidden unemployment.

- Requirements of determining the required specialized workers in sports programs related mainly to accurate determination of the requirements of jobs from duties and responsibilities and analysis of jobs and study of places of work and classification to groups, determination of number of days with basic and additional programs, determination workers from using some suitable statistical method for this purpose as the results showed.

- The best methods and models of human resources planning for sports programs that suit the circumstances of media organization and integrate between them according to facilities of sports programs and media organization belonging to it and preference of models of work centers that depends on determination of characteristics of persons and description of activities and determination of the gap in quantity and quality and development of process of planning continuously with 
necessity of presence of information systems and statistics to make skeletal analysis for workers and ratio of workers to programs and dependence on technology and computer for internal and external environment analysis.

- The most important effective steps for human resources planning to achieve organizational effectiveness for sports programs which is formation of comprehensive system for information about human resources, presence of independent directorate of human resources for sports programs, analysis and determination of human skills and experiences available through analysis of internal and external work environment preferring strategies of growth on stability or shrinkage, prediction of request on human resources with estimation in quantity and quality according to environmental variables, prediction of method of general attitude toward workers data in previous years from increase or decrease, prediction of needs of management,

- Requirements of jobs of human resources planner on level of sports program, effective knowledge from basic concepts in human resources planning for media organizations basic skills from preparation of planning models, knowledge about internal and external environment, assistant knowledge as the results showed.

- Indicators of success of human resources plan in achievement of organizational effectiveness of sports programs as internal indicators as technical skills, job satisfaction, participation in planning, training programs, cost, external indicators as growth, development, technology, competition, survival and continuation.

\section{Recommendations:}

From presenting and discussing the results, the researcher recommends the following :

- Necessity of establishment of independent directorate for human resources to be responsible on planning and putting strategies for human resources on sports programs in Radio and television union.

- Establishing data bases for information of all workers in sports programs.

- Care for requirements of human resources planning in sports programs through application of suggested models to plan human resources to achieve organizational effectiveness for sports programs and take the results of the questionnaire domains for guidance, Figure (1). 
Figure (1)

Model for human resources planning to achieve organiational effectiveness of sports programs in Radio and Teleivison Union

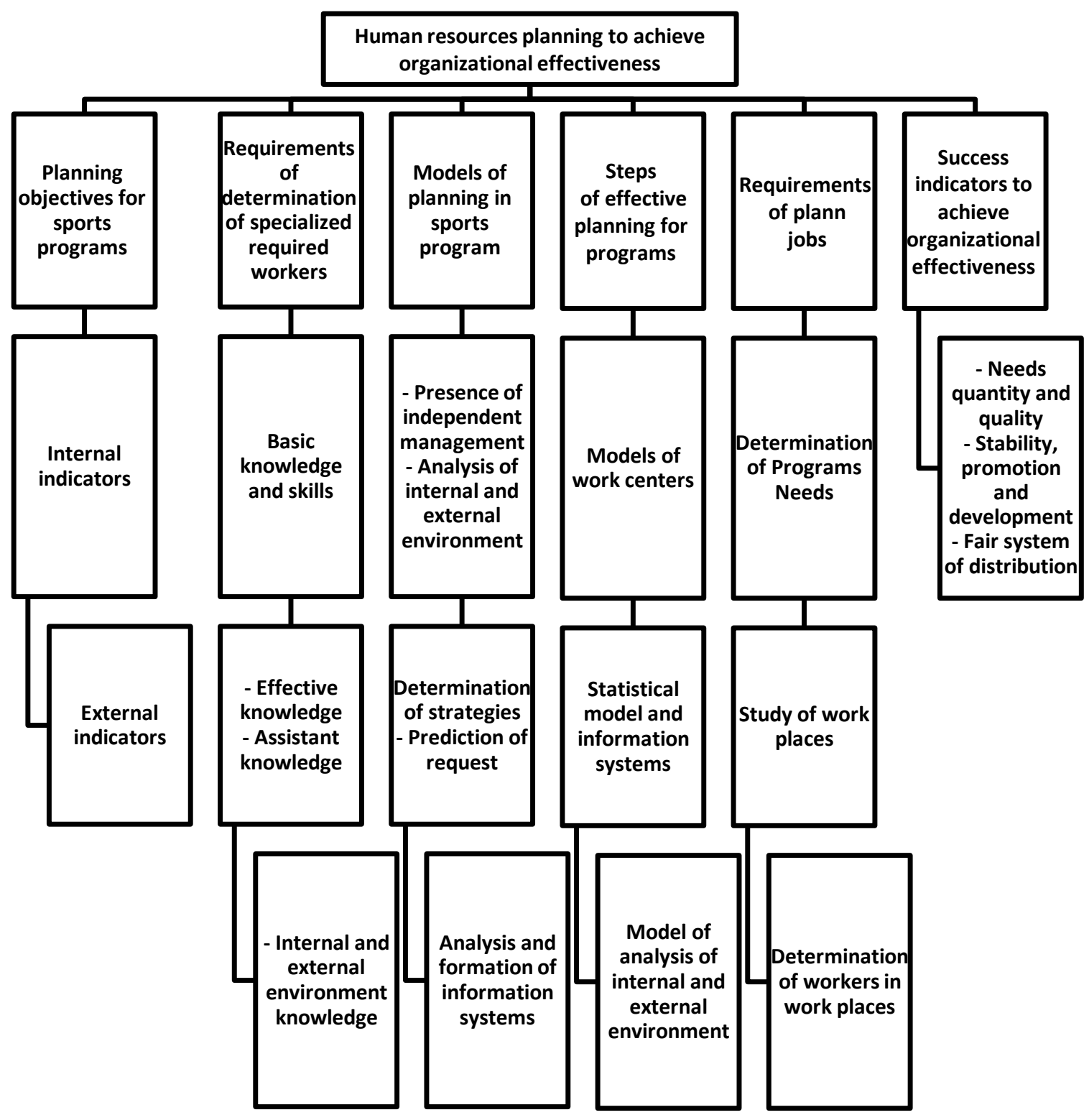




\section{References :}

1. Ashrash .A: 2006,"Role of human resources management in Egyptian business organization within economy of knowledge", Doctorate, Faculty of Commerce, Cairo University,

2. Al-Taher .M: 2005,"Social Responsibility and business ethics", Wael home for publishing,.

3. Khalid .A, 2005,"Human resources management", Weal home for publishing, $2^{\text {nd }}$ ed., Amman, Jordan,

4. Khalil M, Khaidar K: 2000,"Organization theory", Al-Masirah home, Amman,.

5. Suhaila A: 2002,"Human resources management "Strategic approach", Wael home for publishing,.

6. Saleh M, 2004,"Human resources management and facilitating knowledge in service of efficiency and skills, First international meeting about human development and chances of integration in knowledge economy and human efficiencies", Faculty of Law and Economical Sciences, Warqalah University,.

7. Salah Al-Deen .M : 2005,"Human resources management, Contemporary applied approach", University Home, Alexandria,.

8. Salah. H : 2009,"Administrative leadership and its effect in human resources management strategically", Master, Faculty of Administration and Economy, Arabic Academy in Denmark,.

9. Adel .Z: 2003,"Human resources management strategic vision", Arabic books for publishing, Cairo,.

10. Fatemah. A, 2006,"Role of human resources management policies in achieving competitive advantage for public organization in Hashemite Kingdom of Jordan with application on Jordanian University", Doctorate, Faculty of Economy and Political Sciences, Cairo University,.

11. Faisal. S: "Economical newspaper", No. 4796, 28-11-2006.

12. Mervat .H, 2003,"Effect of human resources management polices on development of innovative abilities for workers in the field of programming in computer companies in Arab Republic of Egypt", Master, Sadat Academy for administrative sciences, National Institute for High management,.

\section{Foreign References:}

13. Buck, Jeffrey M.; Watson, John: 2002, "Retaining Staff Employees: The Relationship Between Human Resources Management Strategies and Organizational Commitment" , Innovative Higher Education.

14. Christian S. Nissen: 2013,"What's So Special About Public Service Media Management",International Journal on Media Management. , p69

15. Ronald J. Burke and, Cary L. Cooper: 2005,"Reinventing Human Resource Management Challenges and New Directions",Schulich School of Business, York University in Toronto, Canada . p12

16. RONALD R: 2002,"Organizational Success through Effective Human Resources Management ",QUORUM BOOKS, Westport, Connecticut • London p 5.

17. Mpolokeng, A: 2010,"Effective Human Resource Planning within an Information Technology Organisation",Cranefield College, uk., p6 
